\title{
Recent developments in intellectual property law in Australia with some reference to the global economy
}

\author{
by Susan Crennan
}

\section{INTRODUCTION}

This paper addresses recent developments in Australia in intellectual property law, with some reference to the global economy, and deals with two patent cases, two copyright cases and a designs case.

It is a given that intellectual property laws are closely tied to the economy, these days a global economy. Such laws are intended to strike the correct balance between encouraging innovation and investment on the one hand, and, on the other, securing the interests of industry, indeed society at large, in having access to the spread of knowledge.

The five cases I have chosen to discuss have two aspects in common. First, they have all been decided relatively recently and represent the current state of the law in Australia in respect of the points they decide. Second, they collectively demonstrate that although technological advances pose undeniable challenges for intellectual property laws, some basic concepts, laid down some time ago, have often proved remarkably supple. This is not to deny a body of academic criticism of intellectual property laws which alleges a lack of coherence or a lack of ability to deal with novel technology, particularly in the context of copyright law and the ease of copying with digital technology. Examples of this include David Vaver, "Reforming Intellectual Property Law: An Obvious and Not-so-Obvious Agenda: The Stephen Stewart Lecture for 2008", (2009) Intellectual Property Quarterly 143; and Kenneth Himma, "The Justification of Intellectual Property: Contemporary Philosophical Disputes", Berkeley Center for Law and Technology (2006) Paper 21; http://repositories.cdlib.org/bclt/Its/21.

Rather, it is my intention to provide recent examples of Australian intellectual property laws operating on particular sets of facts and to examine the questions to which these cases give rise.

\section{Burge \& Ors v Swarbrick}

In the designs case, Burge \& Ors v Swarbrick (2007) 232 CLR 336; [2007] HCA 17 a naval architect, Mr Swarbrick, designed and through his private company manufactured, a racing yacht, the JS 9000. In the course of doing so a "plug" was made, that is a handcrafted full scale model of the hull and deck sections of what became the finished yacht. Hull and deck mouldings were reproduced from moulds which were exact, but inverted, copies of the plug.

In proceedings for copyright infringement, Mr Swarbrick contended that the plug and the hull and deck mouldings, were works of "artistic craftsmanship" within the definition of artistic works in section 10 of the Copyright Act 1968 (Cth) ("the Copyright Act"). He had not obtained any protection for them as designs under the Designs Act 1906 (Cth) ("the Designs Act").

The case raised for the first time, in Australia, the question of the proper test for determining whether a work was a work of "artistic craftsmanship" because, in the absence of design protection, under the Designs Act, Mr Swarbrick was only able to rely on such copyright as he had in the works as works of "artistic craftsmanship". Under section 77 of the Copyright Act, copyright protection against three-dimensional reproduction of an artistic work was denied where the "corresponding design" (whether or not registrable under the Designs Act) had been "applied industrially" by or with the licence of the copyright owner. The alleged infringer, Boldgold Investments Pty Ltd ("Boldgold") defended its actions in attempting to reverse engineer the racing yacht by claiming that the plug and the hull and deck mouldings were "corresponding designs" within the meaning of that phrase in section 74 of the Copyright Act and as no designs had been registered by $\mathrm{Mr}$ Swarbrick there was no copyright infringement because of the statutory loss of protection under section 77 .

It was explained in a unanimous judgment that the statutory phrase "artistic craftsmanship" was doubly 
significant for the case. First, it is a species of "artistic work" capable of attracting copyright protection. Second, the phrase has been used recently to supply the discrimen to mark off the perennially problematic overlap between copyright and design protection. The ultimate issue in the case was whether the racing yacht, the JS 9000, embodied "a work of artistic craftsmanship" in the statutory sense.

The historical difficulties with overlap between copyright and design protection, both in the United Kingdom and Australia, are canvassed in the judgment. The court particularly noted the description of the Copyright, Designs and Patent Act 1988 (UK) ("the 1988 UK Act”) by Pumfrey J in Mackie Designs Inc v Behringer Specialised Studio Equipment (UK) Ltd [1999] RPC 717 at 723:

"[i]t was clearly the intention of the framers of [the 1988

UK Act] that copyright protection was no longer to be available to what can be compendiously described as ordinary functional commercial articles".

That Act created a new system for protecting designs of industrial products, partly through copyright law, but more significantly, through dual systems governing both registered and unregistered designs.

To return to the Australian case, Burge v Swarbrick was governed by the Copyright Amendment Act 1989 (Cth) which was designed to overcome the similar copyright/design overlap difficulties dealt with by the 1988 UK Act. It resulted in changes to the Copyright Act. As mentioned, a new section 77 operated to deny copyright protection against three-dimensional reproduction where the "corresponding design" (whether registrable or not under the Designs Act) had been "applied industrially", that is applied to more than 50 articles.

A relevant exception to the operation of these loss of protection provisions was provided in section 77(1)(a) which provided that the loss of protection provisions applied where copyright subsists in artistic work "other than ... a work of artistic craftsmanship". The effect of that provision was that a work of "artistic craftsmanship" retained copyright protection but only if not registered under the Designs Act.

In construing the phrase "artistic craftsmanship" for the purposes of the Australian legislation, the High Court had regard to what Lord Simon of Glaisdale had said in George Hensher Ltd v Restawile Upholstery (Lancs) Ltd [1976] AC 64. This differed considerably from what was said by others who heard the appeal. That case concerned a popular suite of furniture of distinctive design described as "boat shaped" and marketed as the Bronx. The appellants sued for infringement of copyright in respect of the prototype. The copyright relied upon was that in respect of works of "artistic craftsmanship" as provided in the 1956 UK Act.

Lord Simon had recognised the composite nature of the phrase "a work of artistic craftsmanship" and construed it as a whole. He also recognised that there was no relevant distinction between the phrase "a work of artistic craftsmanship" used in the Copyright Act 1956 (UK) and that found in the Copyright Act 1911 (UK), where it had originated. He then referred to the Arts and Crafts Movement and the activities of John Ruskin and William Morris and said it was that movement with its emphasis on "the applied or decorative arts" which prompted the legislature in 1911 to give copyright protection to "works of artistic craftsmanship."

As to a work of craftsmanship, Lord Simon said (at 91):

“'Craftsmanship', particularly when considered in its historical context, implies a manifestation of pride in sound

workmanship - a rejection of the shoddy, the meretricious, the facile."

He then said (at 93):

"Even more important, the whole antithesis between utility and beauty, between function and art, is a false oneespecially in the context of the Arts and Crafts movement. 'I never begin to be satisfied', said Philip Webb, one of the founders, 'until my work looks commonplace.' Lethaby's object, declared towards the end, was 'to create an efficiency of style.' Artistic form should they all held, be an emanation of regard for materials on the one hand and for function on the other."

Lord Simon then asked whether the work under consideration was a work of "one who was ... an artistcraftsman"; in the course of answering that he distinguished between various crafts particularly by reference to functional constraints.

Having approved that approach of Lord Simon, the High Court in Burge v Swarbrick concluded that (at 364):

"It may be impossible, and certainly would be unwise, to attempt any exhaustive and fully predictive identification of what can and cannot amount to 'a work of artistic craftsmanship' within the meaning of the Copyright Act as it stood after the 1989 (Amendment) Act. However, determining whether a work is 'a work of artistic craftsmanship' does not turn on assessing the beauty or aesthetic appeal of work or on assessing any harmony between its visual appeal and its utility. The determination turns on assessing the extent to which the particular work's artistic expression, in its form, is unconstrained by functional considerations."

The appeal was ultimately decided on the basis that the plug was not a work of artistic craftsmanship because the work of Mr Swarbrick in designing it was not that of an artist-craftsman. The evidence had demonstrated that matters of visual and aesthetic appeal were subordinated to the achievement of purely functional requirements. As a necessary corollary the hull and deck moulds were also not works of artistic craftsmanship.

Further amendment to the copyright legislation by the Designs (Consequential Amendments) Act 2003 (Cth) 
intended to further deal with the copyright/designs overlap did not include a recommendation that had been made by the Australian Law Reform Commission that "artistic craftsmanship" should be defined. Accordingly the primary issue decided in the appeal continues to be relevant.

The decision is important for its commercial ramifications and could be of some interest in the United Kingdom, despite a different regime for protecting individual designs, because "original artistic works", as defined in section 4 of the Copyright, Designs and Patents Act 1988 (UK), includes "a work of artistic craftsmanship". It can be noted that in the United States, the Vessel Hull Design Protection Act 1998, 17 USC § 1301, 1302 conferred sui generis protection upon designs for vessel hulls including "plugs" and "moulds."

\section{Lockwood Security Products Pty Ltd v Doric Products Pty Ltd [No 2]}

The second case is a patent case reported as Lockwood Security Products Pty Ltd v Doric Products Pty Ltd [No 2] (2008) 235 CLR 173; [2007] HCA 21 (“Lockwood v Doric [No 2]”). It raised a common dilemma in patent law: namely, the standard of inventiveness sufficient to justify the monopoly of a patent.

Historically, the separate requirement of inventiveness sprang from novelty from which, at first, it was not clearly distinguished. This can be traced easily through a series of cases mostly in the second half of the 19th century (see Crane v Price (1842) 1 Web Pat Cas 393 at 409 per Tindal CJ; Tatham v Dania (1869) Griffin Pat Cas 213 at 214 per Willes J; Britain ${ }_{v}$ Hirsch (1888) 5 RPC 226 at 232 per Cotton LJ; Cole v Saqui (1888) 6 RPC 41 at 44 per Lindley LJ; The Edison Bell Phonograph Corporation Limited v Smith (1894) 11 RPC 389 at 398 per Lord Esher MR).

The requirement of "ingenuity" or "inventiveness" was "a brake" on too ready a grant of patent protection for analogous uses (Lewis Edmunds, The Law and Practice of Letters Patent for Inventions, (2nd ed, 1897 at 84). The requirement of an inventive step and the correlative, that a patent not be granted for an improvement which was obvious, were control mechanisms intended to inhibit the grant of weak or worthless patents which would inhibit the development of improvements well within the skill of the noninventive persons in the relevant art.

Lockwood v Doric [No 2] concerned a lock mechanism. Lockwood's new lock was designed so that when the lock was opened from the outside the inside lock disengaged thus overcoming the problem whereby a person on the inside could become trapped because without a key they could not unlock a deadlocked door from the inside. The main question was whether the new lock involved an inventive step over the prior art or whether it was a step which would have been obvious to a person skilled in the relevant art.
As with an earlier case, Aktiebolaget Hässle v Alphapharm Pty Ltd (2002) 212 CLR 411; [2002] HCA 59 ("Alphapharm”), the court had regard to historical considerations concerning the development of the inventive step requirement and the law concerning obviousness. The High Court in Lockwood v Doric [No 2] restated the position that the requirement of an inventive step balances competing policy considerations as follows (at 194):

"The emergence of the independent requirement for an inventive step, first in case law, then in legislative requirements for patentability as occurred in the United Kingdom, the United States and Australia, has always reflected the balance of policy considerations in patent law of encouraging and rewarding inventors without impeding advances and improvements by skilled, non-inventive persons."

It had been noted in Alphapharm that the term "obvious" first appeared in legislation in the United Kingdom, United States and Australia after detailed judicial exegesis (at 428429 [36] per Gleeson CJ, Gaudron, Gummow and Hayne JJ). Now, the legislatures both here in the United Kingdom and in Australia have laid down a conceptual framework for determining inventiveness and obviousness which in each case is intended to ensure that patents will not be granted without inventiveness over prior art.

The threshold for inventiveness had been raised in the United Kingdom with the introduction of section 3 in the Patents Act 1977 (UK). Membership of the Patent Union had necessitated aligning domestic patent law with the European Patent Convention which involved rebalancing the competing policy considerations adverted to in Lockwood v Doric [No 2]. Before turning to section 3, it needs to be noted that s 2(2) of the Patents Act 1977 (UK) defined the "state of the art" as follows:

"[I]t shall be taken to comprise all matter (whether a product, a process, information about either, or anything else) which has at any time before the priority date of that invention been made available to the public (whether in the United Kingdom or elsewhere) by written or oral description, by use or in any other way."

Section 3 of the Patents Act 1977 (UK) was explicated by Sir Donald Nicholls VC in Mölnlycke AB $v$ Proctor \& Gamble Ltd [No 5] [1994] RPC 49 at 112:

"Under the statutory code ... the criterion for deciding whether or not the claimed invention involves an inventive step is wholly objective. It is an objective criterion defined in statutory terms, that is to say whether the step was obvious to a person skilled in the art having regard to any matter which forms part of the state of the art as defined in section 2(2). We do not consider that it assists to ask whether 'the patent discloses something sufficiently inventive to deserve the grant of a monopoly[']. Nor is it useful to extract from older judgments expressions such as "that scintilla of invention necessary to support a patent'." 
This was a clear rebuff to the notion that it is appropriate to concentrate on the quantum of inventiveness; what is put in the forefront, in the place of quantum is the need to establish the quality of inventiveness.

The prior art base has also been extended in Australia. The Patents Act 1990 (Cth) first defined "prior art base" and "prior art information" and the Patents Amendment Act 2001 (Cth) expanded the prior art base, against which "inventive step" is assessed so as to include public oral disclosures and actions anywhere in the world.

In Lockwood v Doric [No 2] the court recognised that "the problem and solution" approach mandated here in the United Kingdom is useful, however the approach is to be applied with care in Australia so as not to exclude inventions containing a sufficient quantum of inventiveness.

The court found a "scintilla of invention" remains enough in Australia so that Australian law blends considerations of both the quantum and the quality of inventiveness and is therefore quite distinct from the law generated by the European Patent Convention which refers to a "problem and solution" approach to the question of inventive step. In any event it has been recognised that the "problem and solution" approach has its limitations and is not the only way to go about considering obviousness (Actairs UK Limited $v$ Novartis AG [2010] EWCA Civ 82 at [26] and [39] per Jacob LJ).

It is of interest to note that in KSR $v$ Teleflex 127 Sct 1727, 1741-43 (2007) the Supreme Court of the United States of America suggested that courts and patent examiners should go further than considering the "problem and solution approach."

The question of what is the correct threshold for inventiveness can be expected to remain under scrutiny particularly with applications for global patent protection in respect of novel subject matter such as gene patenting. Because genes and genetic products are emerging as both diagnostic and treatment tools for cancer, it may be contended in the future that the balance needs to be restruck between the need for the protection and encouragement of biotechnology innovations and the competing need for the public to have ready access to the benefits of genetic testing and technology.

Certainly, as Professor Cornish observes, the decision of the United States Supreme Court in Diamond $v$ Chakrabart 65 Law Ed. (2d) 144 (1980), which upheld patent protection for a genetically engineered organism which could disperse oil spills, "sent a crucial signal to the world that patenting must be made available in any country which sought to join the race for commercial returns on biotechnological research" (Cornish and Llewellyn, Intellectual Property: Patents, Copyright, Trade Marks \& Allied Rights, 6th ed (2007) at 221, [5-65]).
A not unrelated question is whether the exclusion of methods of medical treatment from patentability under European law should remain (see Directive 98/44/EC on the Legal Protection of Biotechnological Inventions, [1998] O.J. L213/13). Any redrawing of the boundaries of the patent system is inevitably a restriking of the balance which I have mentioned.

Yet another contemporary American context in which an argument has been raised for heightening the threshold of inventiveness (or non-obviousness) is the context of patents for interfaces which may impede interoperability among information and communication technologies: Pamela Samuelson, "Are Patents on Interfaces Impeding Interoperability?”, (2009) 93 Minnesota Law Review 1943 at 1979. That proposal seems referable at least in part to a recognition that patents for interface designs may be sought for anticompetitive purposes, that is as a tool for blocking competitors from developing compatible products and for controlling the market for complementary products.

Finally, there has been continuing public discussion in IP Australia's consultation paper entitled Getting the Balance right: Toward a Stronger and More Efficient IP Rights System (November 2009) about whether the threshold for inventiveness should be raised so as to be more closely aligned with patentability standards in regions which are Australia's major trading partners.

\section{Northern Territory of Australia $v$ Collins and Anor}

The third case is the second of the patent cases, Northern Territory of Australia v Collins and Anor (2008) 235 CLR 619; [2008] HCA 49. This concerned a quite narrow question of contributory infringement.

Mr and Mrs Collins, a married couple, were the joint registered proprietors of an Australian patent for methods of producing essential oils from Cypress pine timber. Such oils were produced for use in aromatherapy. The Northern Territory granted four licences to a company to enter various plantations to take and harvest Cypress pine timber. Mr and Mrs Collins sued the Northern Territory alleging contributory infringement under section 117 of the Patents Act 1990 (Cth) ("Patents Act"). Section 117 relevantly provided:

“(1) If the use of a product by a person would infringe a patent, the supply of that product by one person to another is an infringement of the patent by the supplier unless the supplier is the patentee or licensee of the patent.

(2) A reference in subsection (1) to the use of a product by a person is a reference to:

(a) $\ldots$

(b) if the product is not a staple commercial product - any use of the product, if the supplier had 
reason to believe that the person would put it to that use; or

(c) $\ldots "$

It can be seen that subsection (2)(b) provided what was in effect an exception to the concept of use where the product supplied was a "staple commercial product". The Northern Territory submitted that the timber in question was a staple commercial product within the meaning of section 117(2)(b) of the Act. Section 117 does not refer to the exclusive rights given to exploit the invention for the term of the patent (Patents Act s 13). Section 117 identifies conduct namely the "supply of [a] product" by one to another. Liability for infringement is imposed when "the use of [the] product" by the person to whom it is supplied "would infringe [the] patent".

In considering whether the timber taken under the statutory licences was a "staple commercial product", a reference was made, in the joint judgment of Gummow ACJ and Kirby J, to cognate expressions in both the United Kingdom and the United States (Northern Territory v Collins at 625-26 [24-27]). The evidence in the case showed that the timber under consideration was suitable for use in a variety of applications. The conclusion that the timber in question was a "staple commercial product" was determinative of the appeal. Accordingly, whilst there had been a relevant supply of timber, the supply was not capable of constituting contributory infringement.

Whilst this case was resolved on a narrow basis, the idea of contributory or indirect infringement in patent law influenced the United States Supreme Court in the Sony case (Sony Corporation of America $v$ Universal City Studios (1984) 464 US 417) which involved an infringement-enabling device and the question of whether copyright infringement was made out in circumstances where the device could be used for "substantial non-infringing uses."

The whole area of the liability of businesses for the infringements of their customers is likely to continue to be interesting as the United States Supreme Court further considers secondary liability for copyright infringement. For a discussion of these issues and the cases see Jane C Ginsburg, "Separating the Sony Sheep from the Grokster Goats: Reckoning the Future Business Plans of Copyright Dependent Technology Entrepreneurs", Columbia Law School, Columbia Public Law Research (2008), paper 08-166.

\section{Copyright Agency Limited v New South Wales}

The last two cases for consideration are copyright cases. Copyright Agency Ltd v State of New South Wales (2008) 233 CLR 279; [2008] HCA 35 concerned government copying of material being survey plans compulsorily lodged with relevant authorities. The final case, IceTV $v$ Nine Network Aust P/L (2009) 83 ALJR 585; [2009] HCA 14, concerns copyright in respect of compilations.
Copyright Agency Ltd v State of New South Wales involved a statutory licence scheme under the Copyright Act 1968 (Cth) ("Copyright Act"). As noted in the judgment (at 296-267 [48]):

" $[t]$ he emergence and refinement of statutory licence schemes has been a distinct part of the modern development of copyright law reflecting the competing economic interests of copyright owners and others with a legitimate interest in 'being able to use copyright material on reasonable terms'. The quest to maintain the balance between a public policy encouraging creativity and a public policy of permitting certain uses on some reasonable basis, continues to preoccupy the legislature, particularly as modern techniques for copying, especially digital electronics are 'both immensely efficient and easy to use'." (footnotes omitted)

The appellant, Copyright Agency Ltd, was a recognised collecting society. Collecting societies have become increasingly relevant beyond their original function in respect of musical performance rights. This is because of photocopying technology and more recently new digital technology for the easy distribution of information. One of the members of Copyright Agency Ltd was the Australian Consulting Surveyors Association. Members of the Surveyors Association produced survey plans of land and strata in the state of New South Wales; they owned the copyright in survey plans produced by them.

The survey plans were "artistic works" protected by s 10(1) of the Act. The copyright in the artistic works, the survey plans, included the exclusive right to reproduce the survey plans in a material form (s 31(1)(b)(i)) and to communicate them to the public (s 31(1)(b)(iii)).

Two international treaties signed in Geneva in December 1996, the WIPO Copyright Treaty and the WIPO Performances and Phonograms Treaty, expanded the right of communication to the public, making it an independent and exclusive right consonant with the technology of the Internet. The Copyright Amendment (Digital Agenda) Act 2000 introduced the novel and exclusive right of communication to the public and section 10 of the Copyright Act defines "communicate" as "to make available online or electronically transmit (whether over a path, or a combination of paths, provided by a material substance or otherwise) a work or other subjectmatter". Section 36(1) of the Copyright Act provided that the copyright in an artistic work was infringed by a person who, not being the owner of the copyright, and without the licence of the owner of the copyright, did or authorised the doing in Australia of any act comprised in the copyright.

The survey plans in question were necessary to enable the State to create and maintain an accurate record of land and interests in land. There were legal requirements for the preparation and lodgement of such survey plans. Only registered surveyors could prepare such plans which they did by following certain legal requirements. Typically surveyors charged their clients for the production of survey 
plans. The Registrar-General, Land and Property Management Authority, with whom the plans were lodged was obliged by law to provide copies of registered plans to members of the public upon request. The Copyright Agency Ltd applied to the Copyright Tribunal for a determination of the terms upon which the State could make digital copies of the survey plans and communicate them to the public. In doing so it relied on section 183 which provided a licensing scheme for government use. The scheme of section 183 is to provide that the doing of an act comprised in the copyright in an artistic work does not constitute an infringement of copyright in the work "if the acts done are done for the services of " the State.

The Copyright Agency Ltd argued that section 183 is a statutory licence scheme leaving no room for the implication of a licence to copy the plans or communicate them to the public. It was contended that there was no need to imply a licence when an express statutory licence was available.

The State submitted that in all the circumstances it was not dependent on section 183 to except it from infringement, because it has an implied licence, binding on the owners of the copyright in the plans, to do everything it was required to do within the statutory and regulatory framework which governs the plans. Implicitly the State contended that by reason of the implied licence it had free use of such plans.

The court accepted the appellant's argument. The court recognised that the Act had several licence schemes which developed in tandem with improved techniques for copying of copyright works. It also noted that two related developments in the middle of the 20th century constituted the setting in which a special committee was appointed to reconsider inevitable tensions between the rights of copyright owners and the public need for reasonable access to copyright works.

First, Article 7 of the 1948 Brussels Revision of the Berne Convention for the Protection of Literary and Artistic Works 1886, had provided that the terms of copyright protection shall be for the life of the author plus 50 years after the date of the author's death. This raised the prospect that the system of compulsory licensing then in place would prevent copying long after the economic interest in doing so had dissipated. Second, Crown immunity for copyright infringement was abolished in the United Kingdom which raised the question of Australia following suit and instituting a system whereby the Crown might use copyright material without the risk of infringement. Section 183 had been introduced by the Copyright Act 1968 (Cth) to ensure that the Commonwealth and the States had a right to use copyright material in circumstances where such use was without the owner's consent.

The result reaffirmed the efficacy of the particular statutory licensing system with which it was concerned. It can be expected that statutory licensing schemes will be subject to continual updating as new technologies emerge which simplify copying. A related issue which I simply mention is the burgeoning of "fair use" exceptions to copyright infringement which may call for some future rationalisation.

\section{IceTV Pty Ltd $v$ Nine Network}

The final case, IceTV Pty Ltd v Nine Network concerned a compilation of factual material. Nine Network ("Nine") sued IceTV Pty Ltd ("IceTV") for alleged infringement of copyright in Nine's television programme schedules. These were literary works under section 10 of the Copyright Act as "literary work" includes "a table or compilation, expressed in words, figures or symbols". The case gave rise to the question of whether copyright protection was confined to a particular mode of expression and whether it could be extended to facts or information. Australian legislation has no counterpart to the 1996 Directive of the European Parliament and of the Council on the Legal Protection of Databases.

The appellant, IceTV, published an online television programme guide for use with digital recording devices. The electronic guide was compiled from various sources including the weekly programme schedules compiled and released to the public by television networks. The respondent network claimed that IceTV had infringed copyright in its weekly schedules by directly reproducing details of the titles of its programmes and the times at which they would be broadcast. That information referred to as "time and title" information was claimed by the network to be a substantial part of its weekly schedules of programmes. This gave rise to the submission that IceTV had appropriated the skill and labour of the network's employees in the process of selecting programmes to be screened and placing them in particular timeslots so as to optimise advertising revenue.

One of the interesting issues to which the case gave rise was whether mere "sweat of the brow" in preparing a compilation was sufficient to establish the subsistence of copyright. In Feist Publications Inc. v Rural Telephone Service Co Inc 499 US 340 (1991) the United States Supreme Court rejected the argument that "sweat of the brow" in compiling information was enough and found that some creative spark was necessary to establish copyright in a compilation.

The judgments confirmed the proposition that copyright does not protect facts or information; what copyright protects is the particular form of expression in which facts and information are to be found. It was further held that assessing the substantiality of the part copied should not be carried out at too high a level of abstraction because that created a risk that "ideas" of an author would be protected rather than the expression in a material form of the ideas.

Another interesting aspect of the judgments is the confirmation that originality of the compilation was to be 
determined by reference to the whole of the work. The expression of the "time and title" information was essentially dictated by the nature of that information therefore it lacked originality associated with mental effort or exertion.

Furthermore, all the judges recognised that in assessing whether reproduction of a substantial part of an original work involves an appropriation of skill and labour of the author (or authors) it is necessary to examine the skill and labour and to ask whether it is in fact directed to the originality of the form of expression. In one of the joint judgments, the various stages in the production of the weekly schedules was considered and the three judges in that joint judgment found that the preponderance of steps taken in relation to the production of the weekly schedules were steps directed to Nine's [ie the television network's] business, and that the steps directed to producing the weekly schedule and revising it and making last minute changes involved only modest skill and labour.

Because the expression of the time and title information was essentially dictated by the nature of the information, and involved no particular, or extremely modest, exertion, IceTV's taking and use of the time and title information was found not to amount qualitatively to a reproduction of a substantial part.

One commentator on the decision has pointed out that this decision aligns the Australian law in relation to factual compilations with its major trading partners: Glenn McGowan SC, "IceTV $v$ Nine Network and the copyright in factual compilations in Australia”, (2009) 83 ALJ 840 (at 848):

“- United States - Feist Publications, Inc. v Rural Telephone Co 499 US 340 (1991) where copyright subsistence was denied in telephone books because no creativity and mere sweat-of-the-brow;

- Canada - CCH Canadian Ltd v Law Society of Upper Canada [2004] 1 SCR 339; 2004 SCC 13, roughly applied Feist, finding the exercise of skill and judgment must not be so trivial that it could be characterised as a purely mechanical exercise;

- England and Europe - EU Database Directive 1996, 96/9/EC, March 11, 1996; British Horseracing Board v William Hill [2005] EWCA (Civ) 863 where BHB failed to protect its racing data."

This case is also significant in its rejection of use of copyright for essentially anti-competitive purposes.

The five cases discussed all involved intellectual property issues which transcend national boundaries and some touch upon issues which form part of the ongoing debates in the United Kingdom, the United States of America and Australia, about the scope of patent and copyright law. If one takes copyright as a representative example, the Berne Convention for the Protection of Literary and Artistic
Works 1886 and the revisions thereto, the TRIPS Agreement of 1994 and, as mentioned above, the treaties of 1996 (which build on the Berne Convention), collectively demonstrate the global possibility of relatively uniform standards of national protection, including new provisions creating new exclusive rights in the current world of internet communications.

That still leaves for consideration the argument advanced by Simon Stokes in Digital Copyright Law and Practice, 3rd ed (2009) at 3 that:

\section{"the effect of strengthening copyright law in recent years to address the digital agenda will be to seriously and unjustifiably restrict the dissemination of speech, information, learning and culture while not providing any decisive incentives to the creator." (footnotes omitted)}

In the United Kingdom, the Treasury published the Gowers Review of Intellectual Property on December 6, 2006. More recently on December 16, 2008, the Intellectual Property office published Developing a Copyright Agenda for the 21 st Century. Likewise, in Australia various governmentrun consultations have just been completed or are still in progress in relation to numerous aspects of intellectual property, particularly in relation to the challenges to copyright law posed by new technologies.

In the contemporary global economy, intellectual property also has to be assessed by reference to anticompetitive conduct and the general embrace of competitive market principles in many parts of the world. Whilst public debate about the scope and duration of patent, designs, trade marks and copyright protection will surely continue, individual cases such as those discussed above, show the continual restriking, by the courts, of the balance between a perceived need to reward innovation, investment and original work and the need to ensure fair public access to knowledge, information and culture.

In Making History Now and Then (2008), an historiographical study concerning Britain's Industrial Revolution, David Cannadine makes the point (at pp 83111) that the first half of the 1970 s saw a turning point in the world economy and the West, such that a steady pattern of post World War II economic progress halted. He observes that "by the 1980s it was clear that Britain was in the midst, not just of a new and severe cyclical depression reminiscent of the inter-war years, but of a transformative and scarring process of 'de-industrializing' that was occurring more rapidly that elsewhere in the Western World." One can add to that description of "deindustrializing", the contemporary experience of a global financial crisis and current scepticism about the efficacy of many of the 20th century policies intended to assist developing countries.

Individual intellectual property cases frequently require an understanding of the history and progress of the relevant legislation. What that undoubtedly shows is that 
Anglo-American intellectual property law developed significantly in the late 19 th century as a reflection of the industrial and social progress conventionally associated with the Industrial Revolution: see Adam Mossoff, "The Use and Abuse of IP at the Birth of the Administrative State”, (2009) 157 University of Pennsylvania Law Review 2001 at 2022, and also Susan Crennan, "Obviousness Different Paths Through Scylla and Charybdis", (2007) (71) Intellectual Property Forum 12. Australian intellectual property law followed suit as the second half of the 19th century was a period of great development in Australia, especially in the boom years of the 1870s and 1880s (see Andrew Kenyon, Megan Richardson and Sam Ricketson (eds), Landmarks in Australian Intellectual Property, (2009) at xviii).

\section{CONCLUSION}

In conclusion, may I venture the view that, whatever the economic or technological imperatives for change to intellectual property laws in the 21 st century, certain ideas which blossomed in the last third of the 19th century and in the early 20th century are likely to remain constants. They are that there is great social utility in rewarding inventors and designers with limited monopolies and also in protecting, for a period, the original works specified under copyright legislation. International patent applications now reflect the great interest of China, now the world's sixth largest producer of patent applications, and Japan in becoming major producers of intellectual property. Significant investment in research and development leads to economies which favour the protection given by intellectual property laws.

We are more likely to see relevant intellectual property laws adapting to assimilate new technologies and what they make possible, such as file saving, and remaining relevant to them rather than to see a diminution in the scope of intellectual property laws or in the duration of the protection which such laws give. This may involve greater emphasis on secondary infringement rather than upon infringement by consumers of works available through digital media.

This of course must remain subject always to the general proposition that laws must be fair and capable of obedience. Intellectual property laws, like other rules or laws, must command a social consensus if they are to be enforceable. This is one, but not the only, reason why the policy questions presently debated in the field of intellectual property, particularly patents and copyright, are likely to remain both complex and vigorous.

- The paper is taken from a lecture given at the Institute of Advanced Legal Studies on February 15, 2010.

\section{Susan Crennan}

Justice of the High Court of Australia 